\title{
El plan de rearquitectura de la Revista Argentina de Cirugía Plástica
}

\author{
Gustavo F. GRGICEVIC \\ Doctor en Ciencias de la Administración, Profesor de Anatomía y de Metodología \\ de la Investigación, Universidad Nacional del Nordeste (UNNE), Corrientes, Argentina \\ Editor de la Revista Argentina de Cirugía Plástica \\ www.revistasacper.com
}

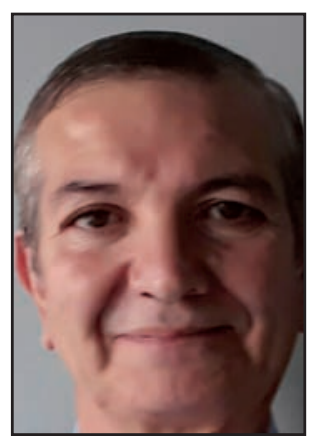

Grgicevic, G.F.
Podemos definir conceptualmente a la Revista Argentina de Cirugía Plástica como el órgano oficial de comunicación de la Sociedad Argentina de Cirugía Plástica, Estética y Reparadora (SACPER). Es la forma documental de relacionamiento de los socios que integran SACPER, bajo el constructo de que SACPER es la entidad científica rectora única de la especialidad.

El principio básico de la ciencia académica es que los resultados de la investigación deben hacerse públicos y ser sometidos a la opinión de los socios a los que va dirigida la comunicación académica. Las técnicas, tácticas y estrategias que se utilizan, diseñan y prueban, en la esfera de la Cirugía Plástica, Estética y Reparadora, para ser consideradas como parte formal del conocimiento científico de la especialidad, deben ser comunicadas a la grey de especialistas formales y registradas de modo permanente, bajo un protocolo exhaustivo. La instancia social de la especialidad es su sistema de comunicación. (John Ziman, 1986).

La esencia de SACPER es el intercambio secuencial de ideas, experiencias y novedades. En cada Congreso Argentino de SACPER, en cada actividad científica que auspicia y desarrolla SACPER, se puede observar el intercambio profuso de ideas por los canales formales y a veces informales, amistosos, basado en la comunicación científica. La esencia es el dialogo formal entre los autores y los participantes del evento. El dialogo conformado debe ser documentado en forma pertinente. He ahí la importancia subyacente y el rol integrador que debe cumplir la Revista Argentina de Cirugía Plástica.

El actual Comité Editor de la RACP fue elegido democráticamente por sufragio de los miembros de SACPER para un período de 4 años. Al comienzo de las actividades editoriales se diseñó un plan estratégico de 4 años de duración que posibilite una rearquitectura, efectiva y eficaz. Los ítems más importantes de este plan son los siguientes:

- Nombre: el nombre de la edición es Revista Argentina de Cirugía Plástica, que es el nombre tradicional, desde su inauguración. Sin embargo, se propone que en un futuro mediato sea reemplazado por Revista de la So- ciedad Argentina de Cirugía Plástica, Estética y Reparadora (REVSACPER).

- Misión: facilitar el relacionamiento científico de los socios de SACPER e incentivar el conocimiento en el campo de la Cirugía Plástica, Estética y Reparadora.

- Visión: ser una publicación referente a nivel internacional, de permanente actualización, con contenidos de calidad y que utilice los modernos mecanismos virtuales de relacionamiento.

- Valores: integridad científica y profesional, respeto y veracidad

- Definición primaria de los campos de interés científico de la RACP: campos de la Cirugía Plástica, Estética y Reparadora. Quemados. Cirugía infantil, cirugía de las malformaciones congénitas y de las enfermedades degenerativas. Cirugía de la mano y de la extremidad inferior. Trasplante y reimplante de miembros y Microcirugía. Cirugía cráneo- maxilofacial. Cirugías para el tratamiento de las disforias de sexo. Técnicas quirúrgicas para trasplantes e injertos. Cirugía oncoplástica, de reconstrucción oncológica y del melanoma. Tratamiento invasivo de lesiones dérmicas y tratamientos de mejoramiento del envejecimiento.

- La comunicación científica a través de la Revista en el entorno de SACPER: define la construcción de una base colectiva de conocimiento; comunica la información científica en forma secuencial, con certezas y celeridad; y sirve para validar la calidad de la información, que es regular, pública, sujeta a normas determinadas y de crecimiento exponencial.

La Revista Argentina de Cirugía Plástica ofrece a los autores la intención de asegurar la propiedad de sus ideas (registro público) y la certeza, de que el conocimiento publicado es válido debido a que está contrastado científicamente y respeta las normas académicas del método científico, y ello, porque ha sido evaluado justa e imparcialmente por el Comité Editorial.

- El nuevo proceso editorial: la RACP, además de comunicar las novedades del entorno SACPER, debe publicar lo respectivos artículos recibidos mediante la implementación de un proceso editorial que contiene un 
reglamento de publicaciones, claro y efectivo. Los artículos recibidos para publicación se someten a un proceso de arbitraje por pares (peer review system) a doble ciego, con formularios ad hoc. Presenta una tabla de contenidos con clara información sobre el proceso de evaluación de los trabajos elegibles para publicación. Se indican las fechas de recepción, revisión, aceptación y publicación de cada artículo recibido. Se refleja claramente, al comienzo del artículo el status del autor, y si presenta condicionamientos en lo referente al conflicto de intereses (si los hubiese).

Cuando se obtiene el número de artículos (5) elegibles para la publicación, se someten a revisión de texto y todos los resúmenes son remitidos para revisión de texto y estilo en inglés. Finalmente se realiza una reunión editorial para elegir una carátula que represente a la RACP. En general, dada la juventud de algunos integrantes del Comité Editorial, se ha optado por pintores de estilos impresionistas. El objetivo direccional es un modelo amigable de RACP, adaptado a las necesidades de los usuarios.

En forma secuencial, el Editor de la Revista presenta un resumen de avances y fortalezas desarrolladas a las autoridades SACPER y obtiene del entorno de su Presidencia la información pertinente a publicar. En lo financiero, RACP no deja aun ganancias a SACPER; pero no produce gastos. En un futuro, se prevé desarrollar un plan de negocios efectivo.

Se ha decidido que la RACP está disponible en el sitio www.revistasacper.com y en www.sacper.org.
- El futuro de la RACP: Teilhard de Chardin define al progreso como la fuerza de la humanidad. Todo está cambiando en pos del progreso. Actualmente, la RACP publica trabajos científicos ya realizados. Son publicaciones ex post. Pero el progreso nos lleva a visualizar trabajos mientras se hacen. En un futuro, estaremos analizando publicaciones ex ante. La necesidad de comunicación e intercambio científico utiliza las herramientas de que dispone. Muchos investigadores, "conversan" virtualmente (whats app, es un claro ejemplo). Es más, son amigos virtuales y no se conocen en forma personal. Es necesario que la RACP esté presente en estos cambios. Seguramente, en un futuro, las publicaciones serán videos, imágenes, intercambios de opiniones y pareceres... Los clásicos congresos y reuniones serán virtuales (ya lo son) y la fluidez del intercambio dependerá del progreso. Iremos abatiendo las fronteras para constituirnos en un conglomerado de pares.

En fin, nos queda un largo recorrido para que la RACP sea un instrumento de referencia. Debemos "convencer" a los investigadores de que les conviene publicar en la RACP. Debemos mantenernos alerta para ver y prever los cambios que nos impone el progreso.

Por último, agradecemos a la Dra. María del Mar Vaquero Pérez la oportunidad de explicar a nuestros pares de Latinoamérica la rearquitectura de nuestra RACP.

revista@sacper.org 